\title{
Informational demand across the globe: toward a comparative understanding of information exchange
}

\author{
Marcel Hanegraaff ${ }^{1 * \star(D)}$ and Iskander De Bruycker ${ }^{2}$ \\ ${ }^{1}$ University of Amsterdam, Department of Political Science, P.O. Box Postbus 15578, 1001 NB, Amsterdam, the Netherlands \\ and ${ }^{2}$ Maastricht University, Department of Political Science, P.O. Box 616, 6200 MD, Maastricht, the Netherlands \\ ^E-mail: M.C.Hanegraaff@uva.nl
}

(Received 09 December 2019; revised 24 March 2020; accepted 26 May 2020; first published online 15 July 2020)

\begin{abstract}
This study examines the information demands of decision-makers from across the globe in their exchanges with interest organizations. It proposes two explanatory factors that drive these information demands: democracy and development. We argue that decision-makers' information demands vary depending on whether they hail from developed countries or developing countries, as well as the extent to which their political systems are democratically accountable. We test our expectations based on interviews with 297 decision-makers from 107 different countries who were active during transnational trade and climate change negotiations. Our findings demonstrate that decision-makers from less developed countries exhibit a higher preference for interactions with organizations that provide them with technical information. Decision-makers from democratically accountable countries, by contrast, tend to place relatively greater value on political information provided by interest groups.
\end{abstract}

Keywords: interest groups; lobbying; transnational conferences; information exchange

\section{Introduction}

The information-exchange perspective on lobbying has become an important model in interest group and international non-governmental organization (INGO) scholarship. This perspective suggests that information is a crucial commodity in lobbying processes (Bloodgood, 2011; Flöthe, 2019a, 2019b; Klüver, 2012; Schnakenberg, 2017; Stroup and Murdie, 2012). As such, interest organizations ${ }^{1}$ provide expertise to time-pressured and understaffed decision-makers in the hope of gaining access or influence in return (Bouwen, 2002; Klüver, 2012). Scholars therefore agree that decision-makers rely heavily on interest groups for policy input (Leech et al., 2005; Bouwen, 2002; Dür, 2008).

To date, the scholarship on information exchange has predominantly addressed the interest group's side of this exchange process, and little research has examined the information demands of decision-makers in their exchanges with interest groups (but see Lucas et al., 2019; Holyoke, 2009; Heaney and Leifeld, 2018). This article seeks to address this gap by asking the following: What are the information demands of decision-makers in their exchanges with interest groups and how can we explain the variation in these demands? Analyzing the information demands of decision-makers is important, as it can lead to crucial insights into the conditions of reciprocity in information exchanges. In other words, interest groups may supply different policy goods to

\footnotetext{
${ }^{1}$ We rely on a broad and functional definition of interest groups, i.e., organizations that seek political influence but have no intention to hold office (Beyers et al. 2008). This definition can include organizations such as business associations, NGOs, labor unions, and firms.

(C) European Consortium for Political Research 2020. This is an Open Access article, distributed under the terms of the Creative Commons Attribution licence (http://creativecommons.org/licenses/by/4.0/), which permits unrestricted re-use, distribution, and reproduction in any medium, provided the original work is properly cited.
} 
decision-makers but may never be rewarded with access or influence if decision-makers do not value the provided policy goods. The information demands of decision-makers are thus consequential for which interest groups prevail in political decision-making. This, subsequently, accounts for potential biases in favor of interest groups that are able to comply with these demands.

In order to explain the information demands of decision-makers, we focus on the domestic context of their countries of origin. We argue that decision-makers from different countries face fundamentally different information abundancies and scarcities and therefore seek other informational input from interest organizations. We propose two key explanatory criteria that vary across countries. The first important distinction can be made based on financial capacities, that is, whether a country is considered 'developing' or 'developed'. The second is the democratic accountability of a political system; in other words, the degree to which governments can be held accountable for their actions by voters through free and fair elections.

We empirically test our contentions based on data obtained from interviews with 297 decisionmakers, from 107 different countries, who were present during transnational trade and climate change negotiations. While some of these decision-makers are diplomats, who may be socialized by the international context, most are civil servants and politicians whose main work terrain is the domestic level. For this reason, focusing on global summits allows us to include policymakers from a wide range of countries and to test whether their domestic origins critically affect the type of information they seek from interest groups.

This paper contributes to current scholarship in three respects. First, it further unravels the exchange relationships between decision-makers and interest groups by focusing on the information demands of the former. We systematically explore what type of information policymakers' value in their exchanges with interest groups. Second, it provides a comparative analysis of these demands in a global context, while taking stock of polity variation related to democratic accountability and economic development. We hope this leads to more attention in the interest group field for lobbying outside Western democracies, hence bridging the gap with the IR literature on global advocacy. Third, it presents a novel database that allows an empirical analysis of the information demands of decision-makers across 107 different countries based on 297 interviews at global diplomatic conferences.

This paper can be divided into four main sections. First, we develop an information-exchange perspective that accounts for different informational features decision-makers value in their exchanges with interest groups. Second, we evaluate the variation in information demands across different countries when formulating research hypotheses. Third, we present our research design and results. We conclude with some closing thoughts and avenues for future research.

\section{Political and expertise-based exchanges}

Lobbying is often conceived of as an exchange between decision-makers and organized interests, where the latter group supplies relevant information to decision-makers and expects to gain access to the political arena or obtain desired policy outcomes in return (Bouwen, 2002; Dür and Mateo, 2013; Klüver, 2013). These exchanges are driven by the fact that decision-makers, in our case international negotiators, face considerable uncertainty in terms of what is feasible in both political and practical terms. Decision-makers need information on the nature and the scope of the societal support they enjoy. However, at times, information gathering on such matters can be extremely difficult, because the principals of decision-makers are not involved in or aware of all of the issues at the negotiating table. In practical terms, decision-makers aim to strike deals that can be implemented and/or do not generate excessive costs for domestic businesses or consumers (Falkner, 2017). In particular, most decision-makers have a generalist orientation and therefore lack the requisite expertise to account for all of the details related to a particular issue or are not always aware of all of the political implications (Hall and Deardorff, 2006). 
While the exchange theory has been mostly developed and tested in Western democracies, there are good reasons to suspect that they are useful in different contexts as well. For instance, Tallberg et al. (2018) and Arras and Braun (2018) find that the provision of expertise to staff of international organizations is an important prerequisite for their influence at these organizations. Furthermore, several studies have found that international negotiators need informational input from interest groups to learn about the political preferences of their domestic industries and civil society, but also to provide them with input regarding the legal provisions, technical feasibility, and the economic impact of certain policies pursued (Tallberg et al., 2018; Arras and Braun, 2018; Lucas et al., 2019). Even though government officials can typically rely on their national civil servants for expertise, interest groups often possess more specialized or even unique information tied to the specific circumstances of the industry or the constituents they represent (Arras and Braun, 2018; De Bruycker, 2016).

The specific informational scarcities faced by international negotiators create opportunities for organized interests that are capable of supplying technical or political information to decisionmakers who rely on this information to reduce the uncertainties they face (Bernhagen and Bräuninger, 2005; Bernhagen, 2013; Holyoke, 2009). Interest groups may offer their expertise to try and sway international negotiators (persuasion) or to get access to the negotiating process in return (exchange), but negotiators are presumed to benefit most from information coming from friendly- or like-minded interest groups that share ideological beliefs and policy goals (subsidy) (Hall and Deardorff, 2006; Lucas et al., 2019). At the international level, it seems likely that interest groups act mostly as 'service bureaus', providing friendly policymakers with the more specialized expertise required for the pursuit of shared policy goals. Indeed, as Beyers and Hanegraaff (2017) find, most interest groups have a rather cooperative relation with policymakers at the transnational level, prioritizing friends in the policy process over foes. From this perspective, our assumption is that the provision of information by interest groups at transnational venues mostly, but not exclusively, takes the form of a 'legislative subsidy', rather than being part of an exchange or persuasion process.

Moreover, we concur with scholars such as Holyoke (2009) that in the dyadic relationships between government officials and lobbyists, the former has the stronger position and decides when and with whom interactions take place. Namely, the decision-maker can stop listening to an interest group, denying it access and influence, if it cannot provide the required information or when the interest group asks too much in return (Braun, 2012: 810). Hence, in the end, it will be mostly the decision-makers determining whether they want to rely solely on legislative subsidies or whether they would be open to exchanges with or persuasion attempts by interest groups. This seems to apply even more strongly to our case. International negotiators and government officials who can rely on the expertise of national civil servants should be less dependent on external information input. Importantly, this means that the demand for information by policymakers is crucially affected by the scarcity of information decision-makers face when active at the conferences. How this demand varies across policymakers active at the global conferences is exactly what we will analyze in this paper.

In their interactions with interest groups, government officials may seek different forms of informational input. Although classifying different types of information demands is not easy (Mahoney, 2008), in the literature one generally finds a distinction between two types of information demands: (1) expertise-based and (2) political. The former refers to the demand for technical or scientific expertise. Technical information comprises substantive expert information about the scientific aspects, feasibility, or effectiveness of a certain policy (Mahoney, 2008; Bouwen, 2002). As said, the supply of this information by interest groups can be seen as part of legislative subsidy or an expertise-based exchange process in which decision-makers seek technical expertise from organized interests and therefore provide the latter group with access or influence in return (Bloodgood, 2011; Bouwen, 2002; Greenwood et al., 1992; Klüver, 2013; Tallberg et al., 2018). 
This is no different in international venues. International negotiators can grant lobbyists access by including them, for instance, in their national delegation or by meeting them personally before or during negotiations. Influence would then imply that the provided information is incorporated into the official position of the government and/or is used by the government officials as arguments in the negotiations. Similar to in a domestic context, there is a need for both technical and political information. About the former, expertise-based information demands are characterized by the need for highly technical and scientific expertise, which is more likely provided by highly specialized and resourceful interest organizations (Flöthe, 2019a). Previous research showed that while business groups and civil society organizations provide technical input to a similar extent, poor or understaffed groups are less likely to comply with the expertise-based demands of policymakers (De Bruycker, 2016; Flöthe, 2019a). Demands for technical information thus foster and reproduce biases in favor of wealthy interest organizations.

Next to technical information, government officials often also seek political information from lobbyists. Political information refers to information about the level of political and societal support for a policy. It is less concerned with the substance of a policy and more with how the policy is supported by relevant stakeholders (see for instance Dür and De Bièvre, 2007; Braun 2013). By supplying political information, an interest organization signals the level of support that policies enjoy, for instance, from the broader public or from a specific constituency such as consumers or the banking industry. Political information coming from opposing interest groups may put political pressure on decision-makers and persuade them to change an existing policy (or keep it unchanged), such that the policy corresponds with the prevailing political views among the represented constituents. Decision-makers value these exchanges to anticipate political opposition that may result in the loss of constituency support or electoral damage (Kollman, 1998; Lucas et al., 2019).

Political information can also serve as a valuable subsidy for government officials in that they are supported or feel bolstered by national constituents and domestic industries on whose behalf they are negotiating on the international stage (Lucas et al., 2019). While government officials can rely on opinion polls, surveys, or other types of information indicating political support in their home country, interest groups are well placed to supply political information about their industry or support base, especially when it comes to specific or complex dossiers (Chalmers, 2013). Interest groups are more prone to supply political information when they are more embedded in society (grassroots organizations), when they have an extensive membership, and when issues are salient in the media. Financial resources, however, do not seem to significantly affect the provision of political information, which makes the provision of political information a bit less exclusive than the supply of technical information (De Bruycker, 2016; Flöthe, 2019a). Importantly, political information is also a critical source of information for policymakers working on international agreements. Indeed, without public support, it is difficult to ratify international treaties and therefore policymakers want to know what the support for proposed policies are in society and among key civil society stakeholders.

In short, while there are important differences between negotiations at the transnational level and in a domestic, Western context, there are also some critical similarities (Hanegraaf et al., 2020). First, while the government-interest group relationship is perhaps more asymmetric than in a domestic scene and information exchanges resemble subsidies more than persuasion, the ontological nature of the relationship is the same: interest groups provide information to policymakers which they lack themselves, and policymakers provide interest groups with access or influence in return. Second, while technical information may be more important at the global level, political information can still be considered a valuable commodity during transnational negotiations. Namely, in order to fine-tune their negotiating strategy, government delegates need information on the political sensitivities which the other negotiating partners are facing. Moreover, decision-makers need to be aware of their own domestic political sensitivities to determine their bottom line and ideal position, as they need to ratify agreements in their national 
legislature once a global deal is reached (Milner and Rosendorff, 1996; Betsill and Corell, 2008). For these reasons, we expect that the basic logic of the resource exchange model should also apply to cases beyond a Western context, something we explore next.

\section{Explaining technical and political demands across polities}

In explaining the supply and demand of political and expertise-based information, the current literature has extensively explored differences across $i$ ) organizational types (e.g. Bouwen, 2002; Dür and De Bièvre, 2007; author), ii) political institutions (e.g. Bouwen, 2002; Chalmers, 2013; Dür and Mateo, 2016), and iii) policy issues (e.g. Mahoney, 2008; Tallberg et al., 2018). In the present study, we cumulatively add to these insights and explore a potential fourth source of variation to explain political and expertise-based exchanges, which is the domestic context of the country of origin of decision-makers. We propose two basic criteria that account for the demands of decision-makers for either political or expertise-based information from interest groups: the level of democracy and the level of development in a country. Each type of information reflects a different view on how state-society relations should be organized. A preference for expertise-based information reflects a technocratic and apolitical relationship with societal actors, in which discretion and rational deliberation dominate. By contrast, a stronger need for political information corresponds to a pluralist and democratic policy-making system that is receptive to public pressure and popular demands.

Drawing on resource dependence theory, we presume that government officials interact with interest groups to obtain valuable technical and political information which they cannot control or acquire by themselves (Braun, 2012). We concur with Braun (2012: 295) that the brokerage position of a government official vis-à-vis interest groups is contingent on the environment in which the official operates. For international negotiators, we expect that their domestic political and economic conditions are crucial aspects of that environment and regulate information demands. The scarcity or abundance of political and technical information available to policymakers at the national level, and the ability of interest groups to supply this information, will regulate decision-makers' demands for these types of information. Hence, we expect that the types of information that decision-makers value vary across polities. Each political system has its own procedures and rules about how state-society relations should be organized and how information should be gathered and processed, and this likely leads to different information demands by decision-makers working in such political systems. We, therefore, cannot take the polity as a constant in information-exchange theory, but instead need to reflect on how differences between political systems affect the interactions between decision-makers and societal interests. Building on these assumptions, the remainder of this section develops testable expectations for each of the two modes of information demand.

First, we expect that the preferences of decision-makers to engage with interest groups vary with the economic development of a country, that is, the size of the economy per capita. We argue that the degree to which a polity is economically developed will especially affect the expertisebased exchanges that decision-makers have with interest groups. Almost all empirical studies on information exchange between interest groups and decision-makers reveal that technical information is the most important currency in these exchanges (Chalmers, 2013; Klüver, 2012; Mahoney, 2008).

However, the demand for technical information may vary across polities (Braun 2012). More importantly, we expect that the economic development of a country impacts government officials' demands for technical information. While the policymakers we analyze are (also) active at the transnational level, the most important source of information is still located at the national level where ministries, universities, think tanks, and other research institutes are located. Producing technical information is however a costly and time-consuming endeavor. Indeed, comparative research has shown that mostly wealthy interest organizations are able to supply technical 
information (Flöthe, 2019a). Hence, we can presume that the supply of technical information by interest groups is less secure in developing countries where societal interests are deprived and lack the financial capabilities to produce and communicate technical expertise. International negotiators from poorer countries hence have a weaker brokerage position vis-à-vis (foreign) interest groups that can supply them with the necessary technical expertise.

Decision-makers from economically prosperous and developed countries, in contrast, face a more steady supply of technical information as the societal interests in their home country enjoy a stronger capacity for producing technical expertise. Moreover, these decision-makers are presumed to have a stronger brokerage position as they have a stronger state capacity, enjoying sufficient expertise and scientific know-how in their home countries to adopt technically sound policy positions. In Western countries, there is a broad range of ministries, universities, think tanks, and other types of institutions that gather information on numerous issues. These institutions have existed for decades, sometimes centuries, combining a sound and steady supply of information and expertise available to decision-makers (Caparrós et al., 2004). The ample supply of technical information and scientific expertise means that decision-makers from developed countries have a lower demand for this type of information because much of this information is available to them through other avenues. This is different for countries that are less economically prosperous. Next to a lower supply of technical expertise by domestic interest groups, these countries often lack the necessary state capacities, that is, the infrastructure and human capital and expertise, to gather technical information by themselves. In less developed countries, there are fewer, and certainly less effective, government institutions, universities, think tanks, and research institutes on which decision-makers can rely for relevant technical or scientific expertise. Moreover, many of the institutions that do exist lack the experience and track records to match their counterparts from developed countries (Wu et al., 2010). As a consequence, we expect that decision-makers from less developed countries will face a more severe scarcity of technical information, which translates into a higher demand for interactions with interest groups that can provide them with this information.

It should be noted that in countries with higher levels of development, technical exchanges are also important and relevant (see for instance Mahoney, 2008; Binderkrantz, 2005; Bouwen, 2002). These states often intervene in very complex policy areas where in-house expertise does not suffice, which amplifies the need for technical information provided by external sources. What we argue, therefore, is that these types of exchanges are, relatively speaking, more important in developing countries compared to developed countries. Overall, this leads us to formulate our first hypothesis:

H1: The need for technical information (compared to political information) is negatively related to the level of development of a country.

Second, in terms of political exchanges, the amount of political information that decisionmakers demand and receive is closely tied to their democratic accountability to citizens in the polity in terms of control mechanisms such as free and fair elections (Mulgan, 2000). A lobbyist may try to supply political information by underscoring the level of support for decision-makers' positions. Such political information may put political pressure on decision-makers and seek to persuade them to change an existing policy (or keep it unchanged) such that the policy corresponds with the prevailing political views among the represented constituents. Decision-makers might submit to interest group pressure to prevent undesirable consequences and to be responsive to public demands (Smith, 2000).

We expect a higher demand for political exchanges by decision-makers from political systems that are more accountable to the public. Decision-makers from such polities can be more inclined to actively gather and process the demands and grievances of both opposing and supporting constituents on a continuous basis, because this allows them to be responsive to public demands and 
manage public grievances that might emerge. Not complying with or ignoring political information may result in the loss of constituency support or even electoral damage (Kollman, 1998; Willems and De Bruycker, 2019). For instance, for government delegates from the US or France, it is crucial to have information on public opinion regarding the issues that they negotiate at the global level. For decision-makers from autocratic countries such as Saudi Arabia or China, such information is less consequential because public opinion and civil society are less potent and more easily controlled. Decision-makers from countries that are less accountable to citizens' preferences can therefore more easily ignore the demands and pressures of constituents. In resource-dependency terms, officials from democratic countries are less capable of controlling or manufacturing political support themselves and are more dependent on political support for survival. All this means that government officials from democratic countries have a relatively weaker brokerage position in their pursuit of political information.

Political information is also critical for policymakers working in the context of global negotiations, especially in countries which are more democratically organized. First, international agreements need to be ratified. It is therefore critical that policymakers know whether there is broad support for policies among citizens and key societal stakeholders, such as civil society and the business community (Milner and Rosendorff, 1996). If these groups indicate that their constituents will not support a deal currently on the table, this is an important signal for policymakers that there is also not enough support to successfully defend the deal at home and thus ratify the agreement. As such, the democratic accountability of countries should affect how much value international negotiators attribute to political information. Hence, the need for political exchanges is likely to be lower than in countries with a higher level of democratic accountability. This leads us to hypothesize that:

H2: The need for political information (compared to technical information) is positively related to the level of democratic accountability in a country.

Third, while the discussion above implicitly presumed that democracy and development independently drive the information demands of decision-makers, we cannot conceive of these phenomena as strictly separated. Our previous hypotheses hold true when processes of economic development and democratization go hand in hand. However, a country may be developed but poorly democratized or vice versa. The question in these cases is what type of information will be most critical to the decision-makers. Table 1 summarizes our more specific expectations regarding the demand for technical and political information across countries with varying levels of development and democracy. First, when a decision-maker's country of origin is highly developed but characterized by a low level of democratic accountability (e.g. Qatar, Russia, China), we expect no competing information demands. These decision-makers will value expert input more than political information, as the former is more consequential to consolidate their country's prosperity and their own hierarchical position. Political information is less relevant for such decision-makers, as they are usually insulated from electoral retaliation, protest, and criticism in the public sphere (Grömping, 2019). In other words, in these countries, technical expertise provides more leverage to organized interests.

By comparison, for decision-makers from countries with a high degree of democratic accountability and a low level of development (e.g. India, Peru, Kenya), competing information demands are immanent. In these cases, policymakers can be presumed to pursue both technical and political expertise and may need to prioritize one type of information exchange over the other. In these cases, we expect decision-makers to prioritize technical information over political information. For such countries, economic reform and financial stability are recurring critical issues on the political agenda and hence electorally consequential (Suri, 2004). These policymakers are heavily dependent on economic prosperity for their political survival and will hence be more inclined to acquire technical input. Moreover, in (democratic) developing countries, citizens value core 
Table 1. Overview of variables used in paper

\begin{tabular}{|c|c|c|c|c|}
\hline Variable & Operationalization & Mean & Min & $\operatorname{Max}$ \\
\hline \multicolumn{5}{|l|}{ Dependent variable } \\
\hline Political vs. technical information & $\begin{array}{l}1=\text { technical information }(n=154) \\
0=\text { political information }(n=143)\end{array}$ & & 0 & 1 \\
\hline \multicolumn{5}{|l|}{ Independent variables } \\
\hline Level of development & $\begin{array}{l}1=\text { low-income countries }(n=48) \\
2=\text { middle-low-income countries }(n=53) \\
3=\text { middle-high-income countries }(n=76) \\
4=\text { high-income countries }(n=120)\end{array}$ & & 1 & 4 \\
\hline $\begin{array}{l}\text { Democracy accountability } \\
\text { Control variables }\end{array}$ & World Governance Indicator of the World Bank & 0.31 & -2.08 & 1.62 \\
\hline Salience & $\begin{array}{l}\text { Self-reported attention for issues in country: } \\
\qquad \begin{array}{l}1=\text { highly salient }(n=123) \\
2=\text { medium salient }(n=135) \\
3=\text { low salience }(n=39)\end{array}\end{array}$ & & 1 & 3 \\
\hline Importance & $\begin{array}{l}\text { Self-reported importance of issue for country: } \\
\qquad \begin{array}{l}1=\text { high importance }(n=91) \\
2=\text { medium importance }(n=142) \\
3=\text { low importance }(n=64)\end{array}\end{array}$ & & 1 & 3 \\
\hline Function of decision-maker & $\begin{array}{l}1=\text { politician }(n=23) ; \\
2=\text { diplomat }(n=53) \\
3=\text { civil servant }(n=183) ; \\
4=\text { other }(n=34)\end{array}$ & & 1 & 4 \\
\hline Size of country & GDP in trillion dollars (World Bank ${ }^{\mathrm{a}}$ ) & 0.53 & 0.01 & 18.62 \\
\hline
\end{tabular}

asee https://data.worldbank.org/

democratic values, such as freedom of expression and political activism, less than citizens in developed nations (Inglehart and Welzel, 2009: 40). Moreover, even if democratic policymakers aim to be as democratically accountable as possible to their citizens, prioritizing technical over political information seems like the most rational choice. As Inglehart and Welzel (ibid.: 34) have indicated, the best guarantee for stable democracies in the long run is economic prosperity. This indicates that when decision-makers from democratic yet poor countries face a scarcity of both types of information, we expect information demands geared at economic prosperity to outweigh information demands that originate from democratic ideals. In resource-exchange terms, we see political information more as a 'luxury good' which is only valuable once a critical level of economic development is in place. All the above implies that we need to consider the interaction effects of development and democracy on policymakers' information demands. This leads to our third hypothesis:

H3: The need for political information only outweighs the need for technical information for decision-makers hailing from both highly democratic and economically developed countries.

\section{Research design}

To test our hypotheses, we present a novel database comprising the information demands of 297 decision-makers active in the fields of trade and climate change. The data were collected at four global diplomatic conferences between 2015 and 2017: the 2015 and 2016 sessions of the Conference of the Parties of the United Nations Framework Convention on Climate Change (COPs), in France and Germany, and the 2016 and 2017 sessions of the Ministerial Conference of the World Trade Organization (MCs), in Kenya and Argentina. These conferences were chosen because they are the most important decision-making forums in two key international policy fields, namely trade and climate change. In addition, policies made in these areas 
affect a wide range of stakeholders and attract many different types of interest groups. Furthermore, both climate change and multilateral trade have clear technical components (e.g. calculating emission standards and tariffs) and political components (e.g. the effects on citizens and business organizations), meaning decision-makers working in these areas need both technical and political types of information. Finally, both forums represent typical instances of international negotiations and policymaking (Davis, 2004; Narlikar, 2010), which supports the external validity of our results. First, decision-making at these forums depends, as in most transnational negotiations, on unanimous support, and it often takes many years before any decisions are made. Second, if decisions are made, they normally embody package deals in which a diverse set of interests are integrated.

At these diplomatic meetings, a small team of three to four research assistants randomly asked decision-makers to participate in interviews of 15 to 30 minutes. The respondents were asked to mention one specific issue that they were working on and to report on their positions regarding this issue and the types of interactions they had had with interest groups, both at home and at the conference. In total, we interviewed 297 international negotiators from 107 different countries (see Appendix 1). Their involvement spanned 12 different issues discussed at the conferences. These decision-makers were diplomats and civil servants, such as ambassadors, consuls, and government attachés who were involved in the negotiations at the respective conferences. We have extensive empirical variation across countries in terms of their levels of democracy and development, which perfectly aligns with the purposes of this paper. Since decision-makers are nested in countries, we have conducted multi-level regressions with random intercepts for the countries from which the decision-makers originate.

All of the respondents were included in the formal national delegations of their countries with the aim of safeguarding the interests of their respective states during the negotiations taking place. This made them eligible to answer questions about their reliance on interest groups for political and expertise-based input. Interviewing decision-makers at global diplomatic conferences provided some advantages regarding our particular question. First, it gave us the chance to talk face to face to a large set of decision-makers from a wide range of countries in a relatively short time span, which would not have been feasible if we had visited negotiators from so many different countries. Second, the interviewed decision-makers were active on similar issues in two different policy fields. This keeps much of the policy-specific idiosyncrasy under control, which increases the robustness of our findings. One could argue that some of the negotiators we interviewed had experience working at the international level and, as a consequence, could be socialized to some extent by the international context. However, we do not see this as problematic for our argument. Namely, even under the assumption of perfect socialization to the international level, international negotiators will still have different information demands depending on the countries they come from, because these information demands are strongly driven by the countries' democratic and economic properties and because most information is gathered and processed in a domestic context. We therefore see socialization as a methodological advantage because it enables us to analyze the information demands of decision-makers from different countries, ceteris paribus in terms of the political venue and social environment in which they are active (see Appendix 2 for more details about the fieldwork).

Next, we describe the variables used in the regression analyses (see Table 2). For our dependent variable, we rely on the following question asked in the survey: 'On this issue, could you indicate which of the following types of information provision by interest groups you value the most?'2 Respondents could choose between technical information on the one hand and political information on the other. This resulted in a dummy variable where groups either preferred to get political

\footnotetext{
${ }^{2}$ In the interviews, we explained clearly to respondents what we consider to be interest groups. As said, these are any type of organization that seeks political influence but has no intention to hold office itself (Beyers et al. 2008).
} 
Table 2. Expected demand for technical and political information by a country's level of development and democracy

\begin{tabular}{lllr}
\hline & \multicolumn{2}{c}{ Level of development } \\
\cline { 3 - 4 } & Low development & High development \\
\hline $\begin{array}{l}\text { Level of } \\
\text { democracy }\end{array}$ & Low democracy & Technical $>$ political & Technical $>$ political \\
\hline
\end{tabular}

or technical information from interest groups on a particular issue. ${ }^{3}$ It is important to add that the question was asked as part of a series of questions related to the contacts of policymakers with interest groups in the lead up to the conferences. In other words, they focused on contacts of policymakers with interest groups from their own country, which fits the intention of the paper: to explain information exchanges between policymakers and interest groups across countries.

The independent variables are country characteristics. The level of development is based on the World Bank classification system, which distinguishes between three categories: developed countries, developing countries, and least developed countries. The categorization is a combined construction of gross national income per capita, the human asset index, and the economic vulnerability index. ${ }^{4}$ For the level of accountability that decision-makers have to the demands of citizens, we rely on the accountability to citizens indicator included in the World Governance Indicator of the World Bank, a widely used indicator to measure the democratic nature of political institutions across the world (Inglehart and Welzel, 2010). This indicator ranges from -2.50 (not accountable) to 2.50 (very accountable). For instance, on this scale, China has a score of -1.59 and Denmark a score of 1.69. The level of development and the level of democratic accountability in our analysis were significantly correlated $(\mathrm{r}=.55, p<.001)$ which caused some problems of multicollinearity (VIF Democracy $>5$ ). This could have been problematic for our analysis, given that we wanted to analyze how both factors have an independent effect on how decision-makers value the content and sources of information. As a conservative approach, we first analyzed the effect of democracy and development in separate models. In the next step, to disentangle their multiplicative effects, we employed additional regression analyses in which development and democratic accountability were both included and interacted.

We also included a set of control variables. The first is the importance of an issue for a country. The question asked was 'In comparison to other issues your country works on, how important would you say this specific issue is?' Answers were measured on a scale of 1 to 5 . It could have very well been the case that international negotiators invest more in issues which they perceive to be important for their country, thus valuing different types of information. Second, we controlled for the salience of an issue in a country. The question asked was 'How much attention from the media and the public does this issue attract in your country?' Responses were measured on a scale of 1 to 3 . We expected that on issues for which policymakers perceive a great deal of media attention in their country, political information becomes more important for them. Third, we controlled for the type of decision-maker: elected official, diplomat, civil servant or other (such as working for a specialized agency). We asked each of the respondents what their function was. It could very well have been the case that elected officials value political information more than

\footnotetext{
${ }^{3}$ The interviews were centered around several policy issues discussed at the climate conferences or the WTO. These issues were identified through qualitative interviews held prior to the fieldwork with both policymakers and non-state actors, as well as an analysis of the provisional agendas of the COPs and MCs, draft agreements, position papers and media reports. An example of an issue discussed at the COPs is how to deal with loss and damage associated with the adverse effects of climate change, such as extreme weather events and slow onset events (see Lucas et al., 2019).

${ }^{4}$ See: http://www.un.org/en/development/desa/policy/cdp/ldc_info.shtml
} 
Table 3. Distribution of information demands by type of country $(n=297)$

\begin{tabular}{llr}
\hline & \multicolumn{2}{c}{ Type of information } \\
\cline { 2 - 3 } & Technical & Political \\
\hline Level of democracy & & \\
$\quad$ Democratic & $62(21 \%)$ & $89(30 \%)$ \\
$\quad$ Non-democratic & $67(23 \%)$ & $66(22 \%)$ \\
Level of development & & $80(27 \%)$ \\
$\quad$ High & $40(13 \%)$ & $83(28 \%)$ \\
Low & $94(32 \%)$ & cow
\end{tabular}

Note: Democratic (Polity $=>8$ ); non-democratic (Polity $<$ ). Highly developed (high=high-income countries; low=low-income to middle-high income).

decision-makers who are not held accountable at the ballot box, such as civil servants. Finally, we controlled for the size of country in order to exclude the potential effect that contacts in large countries, such as the United States, provide different results than contacts in small island states such as Vanuatu (Hanegraaff and Poletti, 2020).

\section{Results}

We start by presenting some descriptive statistics. In Table 3, we list all the answers of the respondents in a cross table. Several observations warrant attention. First, we see that, overall, the supply of technical information by interest groups is slightly more important to decisionmakers than the supply of political information. Political information is mentioned 143 times (48\%; see bottom row: 58 plus 85 ) by the respondents as the most important policy good to exchange with interest groups. Technical information is mentioned by a total of 154 respondents (52\%). What this observation mostly indicates is that political and technical information are almost equally important currencies for interest groups to gain access to decision-makers, which reflects findings of earlier studies focusing on exchanges between interest groups and decisionmakers (Chalmers, 2013).

This brings us to the key focus of our study: what explains variation in the need for expertisebased or political exchanges? As argued, our dependent variable is measured on a dichotomous scale based on whether the respondents mentioned a type of content or source as more important than the other when interacting with interest groups. The variable gauging content preference was labeled ' 1 ' when the decision-maker preferred technical to political information and ' 0 ' when political information was preferred. To take into account the nature of these dichotomous variables, we relied on mixed-effects binary logistic regression analyses. Since decision-makers are nested in countries, these logit regressions were conducted with random intercepts for the countries from which the decision-makers originate. Furthermore, as explained in the section on the research design, we controlled for issue characteristics (salience and importance of issue for decisionmaker), the function of the decision-makers in question (elected official, diplomat, civil servant, or other), and the size of the country (in terms of GDP). Models 1 and 2 set out to explain why decision-makers prefer to gain technical or political information from an interest group on a particular issue; Model 3 adds the interaction between democracy and level of development. The results are summarized in Table 4. It should be noted that to further disentangle the effect of democratic accountability and development combined, we also present an interaction between both variables in the final section of the empirical analysis.

We start by explaining the different types of information valued. As mentioned, we draw a distinction between decision-makers preferring political information and those preferring technical information. We explain this based on the level of democracy and development 
Table 4. Mixed-effects binary logit regression of demand for technical (1) or political information (0)

\begin{tabular}{|c|c|c|c|}
\hline & Model 1 & Model 2 & Model 3 \\
\hline \multicolumn{4}{|l|}{ Independent variables } \\
\hline \multicolumn{4}{|l|}{ Level of development } \\
\hline High income & Ref. & & \\
\hline Medium-high income & $\begin{array}{c}0.606^{\star} \\
(0.332)\end{array}$ & & \\
\hline Medium-low income & $\begin{array}{l}1.245^{\star \star \star} \\
(0.393)\end{array}$ & & \\
\hline Low income & $\begin{array}{l}0.918^{\star \star} \\
(0.412)\end{array}$ & & \\
\hline Democratic accountability & & $\begin{array}{l}-0.330^{\star \star} \\
(0.148)\end{array}$ & \\
\hline \multicolumn{4}{|l|}{ Interactions } \\
\hline Less developeddemocracy & & & $\begin{array}{r}0.132 \\
(0.241)\end{array}$ \\
\hline Highly developed ${ }^{\star}$ democracy & & & $\begin{array}{l}-0.686^{\star \star \star} \\
(0.209)\end{array}$ \\
\hline \multicolumn{4}{|l|}{ Control variables } \\
\hline $\begin{array}{l}\text { sallence or Issue } \\
\text { High }\end{array}$ & Ref. & Ref. & Ref. \\
\hline Medium & $\begin{array}{c}0.500^{\star} \\
(0.271)\end{array}$ & $\begin{array}{l}0.912^{\star \star} \\
(0.430)\end{array}$ & $\begin{array}{c}0.458^{\star} \\
(0.272)\end{array}$ \\
\hline Low & $\begin{array}{l}0.867^{\star \star} \\
(0.400)\end{array}$ & $\begin{array}{l}0.541^{\star \star} \\
(0.268)\end{array}$ & $\begin{array}{l}0.817^{\star \star} \\
(0.395)\end{array}$ \\
\hline \multicolumn{4}{|l|}{ Importance of issue } \\
\hline High & Ref. & Ref. & Ref. \\
\hline Medium & $\begin{array}{r}0.251 \\
(0.292)\end{array}$ & $\begin{array}{r}0.173 \\
(0.285)\end{array}$ & $\begin{array}{r}0.157 \\
(0.287)\end{array}$ \\
\hline Low & $\begin{array}{r}0.442 \\
(0.380)\end{array}$ & $\begin{array}{r}0.245 \\
(0.365)\end{array}$ & $\begin{array}{r}0.293 \\
(0.370)\end{array}$ \\
\hline \multicolumn{4}{|l|}{ Function decision-maker } \\
\hline Politician & Ref. & Ref. & Ref. \\
\hline Diplomat & $\begin{array}{r}0.215 \\
(0.501)\end{array}$ & $\begin{array}{r}0.226 \\
(0.498)\end{array}$ & $\begin{array}{r}0.311 \\
(0.504)\end{array}$ \\
\hline Civil servant & $\begin{array}{r}-0.123 \\
(0.441)\end{array}$ & $\begin{array}{l}-0.034 \\
(0.442)\end{array}$ & $\begin{array}{r}-0.049 \\
(0.443)\end{array}$ \\
\hline Other & $\begin{array}{r}-0.745 \\
(0.565)\end{array}$ & $\begin{array}{l}-0.616 \\
(0.564)\end{array}$ & $\begin{array}{c}-0.614 \\
(0.559)\end{array}$ \\
\hline GDP & $\begin{array}{r}-0.104 \\
(0.144)\end{array}$ & $\begin{array}{l}-0.181 \\
(0.159)\end{array}$ & $\begin{array}{c}-0.118 \\
(0.144)\end{array}$ \\
\hline \multicolumn{4}{|l|}{ Diagnostics } \\
\hline Constant & $\begin{array}{l}-1.124^{\star \star} \\
(0.538)\end{array}$ & $\begin{array}{l}-0.471 \\
(0.472)\end{array}$ & $\begin{array}{r}-0.210 \\
(0.484)\end{array}$ \\
\hline Country-level intercept & $\begin{array}{r}0.000 \\
(0.000)\end{array}$ & $\begin{array}{r}0.003 \\
(0.263)\end{array}$ & $\begin{array}{r}0.000 \\
(0.000)\end{array}$ \\
\hline Log-likelihood & -191.363 & -194.338 & -191.369 \\
\hline $\mathrm{N}$ & 297 & 297 & 297 \\
\hline
\end{tabular}

Notes: The model is a mixed-effects logistic regression which estimates a random intercept for each 107 countries (not shown). The dichotomous-dependent variable is the content of information-exchange logit coefficients, standard errors (in parentheses), and significance are presented, whereby: ${ }^{\star} P<0.1 ;{ }^{\star \star} P<0.05 ;{ }^{\star \star \star} P<0.01$.

(see Table 4, first two columns). First, we observe a clear relationship between the level of development in a country and the demand for either technical or political expertise (Model 1, Table 4). That is, the less developed the country of origin, the more likely decision-makers are to value technical information over political information from interest groups, while decision-makers from countries with higher levels of development are more prone to value political information rather than technical information. More specifically (see Figure 1, left), decision-makers from countries with lower levels of development have a predicted $60 \%$ probability of preferring technical 

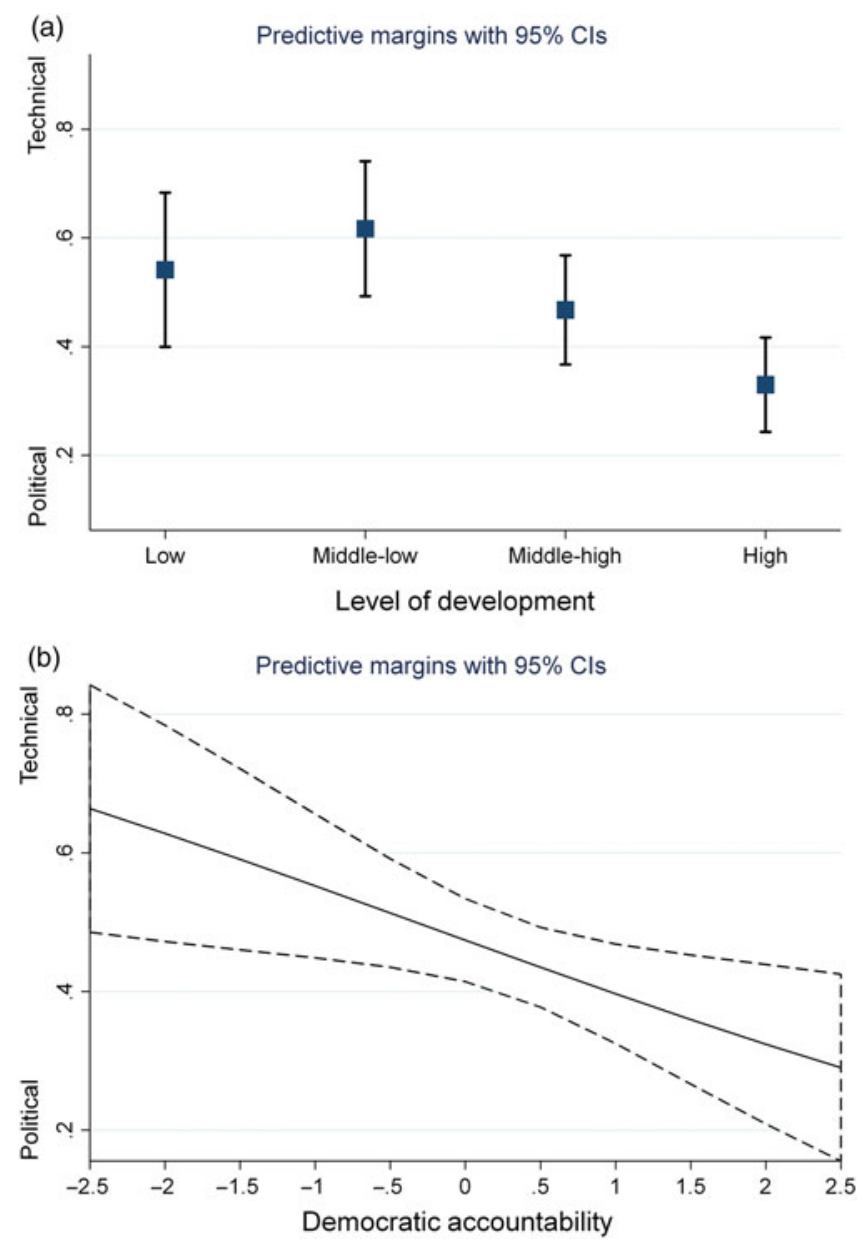

Figure 1. Higher demand for technical $(=1)$ or political information $(=0)$ by level of development (top) and democracy (bottom).

information to political information, based on Model 2. For decision-makers from developed countries (i.e. high-income countries), this probability is only $30 \%$. This means that there is a substantial difference in the relative need for technical and political information depending on the level of development of a decision-maker's country. This finding is important, because it means that decision-makers in developing countries are relatively more dependent on technical information, which makes them potentially more vulnerable to 'policy capture' by special interests. That is, if decision-makers lack the necessary resources, human capital and infrastructure to produce technical and scientific expertise themselves, they are dependent on the often one-sided and potentially biased information flow that interest organizations provide to them. This finding confirms hypothesis 1 .

In terms of democratic accountability, we see a similar pattern. Being democratically accountable has a positive and significant effect on the need for political information and thus less need for technical information. Again, the differences are substantial. Decision-makers from countries with lower levels of democracy have a predicted $30 \%$ probability of preferring political information to technical information, based on Model 2 (see Figure 1, right). For decision-makers from democratic countries, this probability is more than $75 \%$. This means that there is a substantial difference 


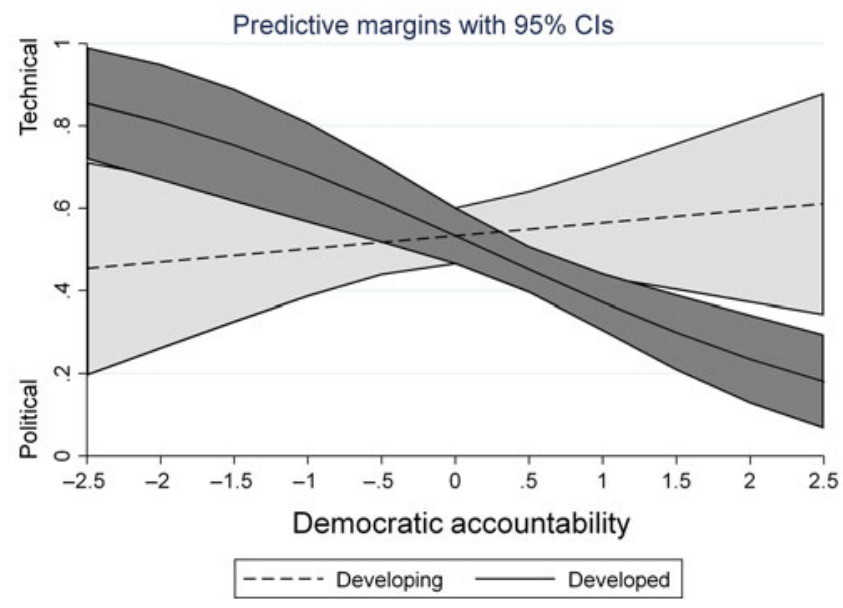

Figure 2. Interaction between democracy and level of development for content.

in the relative need for technical and political information depending on the level of development of a decision-maker's country. Not complying with or ignoring political information is not an option in countries with a high level of democratic accountability because it leads to a loss of constituency support and, in the long term, to electoral damage (Bloodgood, 2011; Kollman, 1998). The opposite applies to delegates from countries with lower levels of democratically accountable institutions. For these decision-makers, such information is clearly less important because public opinion is easier to control and electoral retribution less plausible. This result confirms hypothesis 2.

To explain why policy delegates prefer technical to political input from interest groups, we can thus conclude that the democratic accountability of a country and the level of development matter a great deal. This confirms that the institutional context of a country determines the type of information exchanges decision-makers and interest groups engage in. Also, this confirms the usefulness of the information-exchange model to understand patterns of transnational lobbying. More broadly, this implies that, although lobbying in modern Western democracies is often seen as hindering or bypassing democratic representation, our findings indicate that in democratically accountable countries, interest groups can also play a vital role in elucidating public pressures and demands to policy delegates. The opposite can be said for groups active in less democratic systems. Interest groups giving a voice to opponents or dissidents among citizens and civil society are less important actors for decision-makers from these countries. Overall, we thus find convincing empirical support for our expectation that increased democratic accountability in a country leads to decision-makers valuing political information more.

Finally, to further disentangle the effects of development and democracy and assess $\mathrm{H} 3$, we included an interaction term between these two variables in our models. ${ }^{5}$ The results of the regression analysis are presented in Model 3 (Table 4), and the predictive margins are presented in Figure 2. The findings demonstrate that the democratic accountability of a decision-maker's home state only matters if that country is also developed. That is, if a country is not democratic but highly developed (e.g. Qatar), there is hardly any demand for political information. Yet, for decision-makers from highly democratically accountable countries, we see that the need for technical information becomes less prevalent when their countries are highly developed. Finally, when a country is not developed, the level of democratic accountability of a decision-

${ }^{5}$ In this case we collapsed the developing countries in one category and juxtaposed this to the developed countries. 
maker's home state does not have a significant impact on information demands. Namely, the need for political and technical information remains rather stable and verges more toward technical information. This indicates that once decision-makers face a scarcity of both types of information, the need for technical expertise prevails. In short, information demands that result from economic needs outweigh information demands that originate from democratic ideals. These findings are in line with hypothesis 3 .

To summarize, it seems that as countries develop from low income to high income, and from less democratically accountable to more democratically accountable, decision-makers' need for technical information diminishes. Yet, once countries climb the economic development ladder, this opens the door to information exchanges driven by democratic accountability. That is, when decision-makers' countries are developed, the types of interactions they entertain with interest groups shift quite drastically and they (need to) become much more sensitive to political input.

Some control variables deserve attention. First, perceived salience matters a great deal for the content of the information required by decision-makers. Once decision-makers believe that issues have become more salient in their country, they have a substantially higher demand for political information. While this is not the main focus of our paper, this finding deserves follow-up research, which could focus specifically on the role of issue characteristics affecting information exchanges. Also interesting is the lack of explanatory power for the specific function of the decision-maker. Surprisingly, it does not seem to matter whether a decision-maker is an elected official or not. This contrasts with certain recent findings, which highlight that interest groups adjust their political message to the type of decision-makers they address (De Bruycker, 2016). On the one hand, this may indicate that policymakers are strongly socialized by the international context and are therefore acting in a similar manner. Yet, most of the civil servants and politicians are primarily active at the national level (working in national ministries and parliaments), while the diplomats are mostly active at the global level. In other words, if socialization was driving these results, we should find important differences between diplomats on the one hand, and civil servants and politicians on the other. This means that the national context still matters a lot for the type of information policymakers need from interest groups, even if these policymakers are active at the transnational level.

Finally, we did an additional robustness check to gain even more insight into the importance of the global and national context for the demand of particular types of information by policymakers. This entailed analyzing separate statistical models for the two conferences (WTO and COP, see appendices 3 and 4). The analyses illustrate that our main findings apply to both transnational conferences. This is again a strong signal that policymakers are strongly driven by the domestic context and less so by the global context. In other words, while negotiation forums are very different in terms of the nature of the issue, the progress made during the negotiations, the media attention, and type of actors involved (Lucas et al., 2019; Hanegraaff, 2015), we find that the same information-exchange mechanisms hold true across transnational venues. We are therefore confident that information demands of decision-makers are, at least to a large extent, driven by their domestic context, and more specifically, the level of development and democracy of their home country.

\section{Conclusion}

The information-exchange perspective is among the most frequently used theoretical approaches in interest group scholarship. Most studies to date have addressed the supply side of interest groups in information exchanges with decision-makers (see for instance Flöthe, 2019a; Tallberg et al., 2018; Klüver, 2013; Chalmers, 2013; De Bruycker, 2016). Our paper has contributed to this literature by focusing on the decision-makers' side of information exchanges and seeking to explain variation in the information demands of decision-makers across the globe in their exchanges with interest groups and INGOs. We cumulatively built on the current literature 
that studies differences across organizational types, political institutions, and policy issues (e.g. Mahoney, 2008; Tallberg et al., 2018, Bouwen, 2002; Dür and De Bièvre, 2007; Hanegraaff, 2019) by exploring the country level as a potential source of varying information demands.

The results indicate that decision-makers value both political and technical information. This finding validates studies highlighting these two elements as key currencies for information exchanges between groups and decision-makers. Moreover, we found that variation in the demand for either type of information can be explained on the basis of the domestic context of a policymaker's country of origin. More specifically, we argued that democracy and development affect the relative need of decision-makers to engage in expertise-based or politically driven exchanges.

First, the results reveal that our notion of politically driven exchanges is valid and can be adequately explained by the democratic accountability of a decision-maker's country of origin. Specifically, decision-makers from countries which are more democratically accountable place a relatively greater value on political information than decision-makers from less democratically accountable countries.

Second, our notion of expertise-based exchanges also proved valuable in accounting for variation in the information demands of decision-makers. Although technical information is highly valued by decision-makers from across the globe, the demand for technical information varies according to the level of development of political systems. Decision-makers from less wealthy countries have a relatively greater need for technical information provided by interest groups. Indeed, this effect is so strong that it trumps the positive effect democracy has on the openness of decision-makers to political information. Our results indicate that the need for political information only outweighs demands for technical information if a decision-maker's country of origin is both highly democratic and developed. This confirms our expectation that political information can be seen as more of a 'luxury good', useful in some particular circumstances, while technical information is more a 'necessity good' for interest groups seeking to exchange information for political influence with policymakers.

The results of our study contribute to several debates, but there are also limitations which warrant further exploration. First, the analysis demonstrated that the information-exchange model is applicable beyond the northern hemisphere and demonstrated that, although the exchange perspective travels well from one polity to another, information demands also vary across polities (see also Braun, 2012). As such, future single-polity studies can draw on our findings to situate the external validity of their results. The external validity of findings about the information demands of decision-makers may be limited because we revealed that these demands vary significantly across countries. Other comparative interest group studies, analyzing and comparing different polities, should take stock of the different informational commodities valued in more or less democratically accountable and developed countries.

There is much more room for future studies to extend our framework, especially with regard to the relation between institutional characteristics and information exchange. For instance, to date, there has been no analysis of the differences between interest mediation systems (neo-pluralist and corporatist), the information supply in authoritarian regimes, and many other factors across countries that affect information exchanges. In addition, how do the information demands of decision-makers relate to the influence of interest groups? Although we know that the type of information that groups in Western countries supply significantly affects the influence that interest groups have in the political arena (Dür et al., 2015; Klüver et al., 2015), this is much less clear in developing countries. Finally, it is important to stress that we focused on decision-makers active in global climate change and trade negotiation rounds. While our results suggest otherwise, it is still possible these politicians and civil servants are socialized at the international level and face different information demands in the international arena than in their home countries. Therefore, we cannot readily generalize our findings to national politics or other political arenas. Our hope is 
that this paper can stimulate future research into analyzing the side of policymakers in lobbying exchanges. We would particularly welcome comparative studies analyzing the exchange relations between national decision-makers and interest groups across countries. With regard to all these avenues for future research, we consider the information-exchange perspective an essential ingredient to understanding why decision-makers and interest groups interact in Western and non-Western countries, and ultimately, what consequences this may have for the citizens living in these countries.

Second, our findings are also important for the scholarship on transnational advocacy. Tallberg et al. (2018) have already highlighted the usefulness of the resource-exchange perspective to explain patterns of lobbying in international organizations. They have demonstrated that access to the UN and the UN Environment Programme is more often granted to groups that provide staff at these organizations with valuable information. We extended this approach by demonstrating that decision-makers seek different types of information when active in transnational negotiations as well, which further substantiates the applicability of our approach to the scholarship on transnational advocacy. Furthermore, such studies can serve as a hub between the currently mostly divided scholarship on interest groups in comparative politics and in international relations. By relying more on a common toolset of theories across different disciplines, our understanding of lobbying and advocacy will be greatly enhanced (see also Dellmuth and Bloodgood, 2019; Hanegraaff, 2015). We therefore hope more cross-fertilization between these two fields will emerge in the future.

Finally, our findings also come with important normative implications. First, the fact that decision-makers from developed countries are so dependent on the technical input of lobbyists opens the door for capture by resourceful organizations. That is, acquiring technical information tends to be more expensive than acquiring political information, and business groups are more likely to possess this type of information (Dür and Mateo, 2016; Flöthe, 2019a). Hence, business groups and organizations that are more resourceful seem to be better placed to capture the attention of policymakers in less developed countries. As indicated by our findings, this applies to poor democracies as well. In other words, our results indicate that in developing countries, potential 'policy capture' may occur by groups possessing technical expertise, and this implies that this capture is also open to the highest bidder. While the quality of this policy capture cannot be evaluated with the available evidence, these results clearly warrant further investigation into how interest group politics is biased toward wealthy organizations in the developing world.

Acknowledgements. The author(s) disclosed receipt of the following financial support for the research, authorship, and/or publication of this article: We thank the European Research Council (ERC-2013-CoG 616702-iBias, principal investigator Jan Beyers) for its financial contribution. We also benefited from the financial support of the NWO (Hanegraaff VENI Grant: 45116-016).

Supplementary material. To view supplementary material for this article, please visit https://oi.org/10.1017/ S1755773920000284.

\section{References}

Arras, S. and C. Braun (2018) 'Stakeholders wanted! Why and how European Union agencies involve non-state stakeholders', Journal of European Public Policy 25(9): 1257-1275.

Betsill, M.M. and E. Corell (2008) Introduction to NGO diplomacy. NGO diplomacy: The influence of nongovernmental organizations in international environmental negotiations, 1-18.

Bernhagen, P. (2013) 'When do politicians listen to lobbyists (and who benefits when they do)?' European Journal of Political Research 52(1): 20-43.

Bernhagen, P. and T. Bräuninger (2005) 'Structural power and public policy: A signaling model of business lobbying in democratic capitalism', Political Studies 53(1): 43-64.

Beyers, J., R. Eising and W. Maloney (2008) 'Researching interest group politics in Europe and elsewhere: much we study, little we know?' West European Politics 31(6): 1103-1128. 
Beyers, J. and M. Hanegraaff (2017) 'Balancing friends and foes: Explaining advocacy styles at global diplomatic conferences', The Review of International Organizations 12(3): 461-484.

Binderkrantz, A. (2005) 'Interest group strategies: Navigating between privileged access and strategies of pressure', Political studies 53(4): 694-715.

Bloodgood, E.A. (2011) 'The interest group analogy: international non-governmental advocacy organisations in international politics', Review of International Studies 37(1): 93-120.

Bouwen, P. (2002) 'Corporate lobbying in the European Union: the logic of access', Journal of European Public Policy 9(3): 365-390.

Braun, C. (2012) 'The Captive or the Broker? Explaining public agency-interest group interactions', Governance 25(2): 291-314.

Braun, C. (2013) 'The driving forces of stability: Exploring the nature of long-term bureaucracy-interest group interactions', Administration \& Society 45(7): 809-836.

Caparrós, A., J.C. Péreau and T. Tazdaït (2004) 'North-South climate change negotiations: a sequential game with asymmetric information', Public Choice 121(3-4): 455-480.

Chalmers, A. (2013) 'Trading information for access: informational lobbying strategies and interest group access to the European Union', Journal of European Public Policy 20(1): 39-58.

De Bruycker, I. (2016) 'Pressure and expertise: Explaining the information supply of interest groups in EU legislative lobbying', Journal of Common Market Studies 54(3): 599-616.

Dellmuth, L.M. and E.A. Bloodgood (2019) 'Advocacy group effects in global governance: Populations, strategies, and political opportunity structures', Interest Groups \& Advocacy 8(3): 255-269.

Davis, C. (2004) 'International institutions and issue linkage: Building support for agricultural trade liberalization', American Political Science Review 98(1): 153-169.

Dür, A. (2008) 'Interest groups in the European Union: How powerful are they?' West European Politics 31(6): 1212-1230.

Dür, A. and D. De Bièvre (2007) 'Inclusion without influence? NGOs in European trade policy', Journal of Public Policy 27(1): 79-101.

Dür, A. and G. Mateo (2013) 'Gaining access or going public? Interest group strategies in five European countries', European Journal of Political Research 52(5): 660-686. doi: 10.1111/1475-6765.12012

Dür, A., P. Bernhagen and D. Marshall (2015) 'Interest group success in the European Union: When (and why) does business lose?' Comparative Political Studies 48(8): 951-983.

Dür, A. and G. Mateo (2016) Insiders Versus Outsiders: Interest Group Politics in Multilevel Europe. Oxford: Oxford University Press.

Falkner, R. (2017) Business Power and Conflict in International Environmental Politics. London: Springer.

Flöthe, L. (2019a) 'The costs of interest representation-a resource perspective on informational lobbying', European Political Science Review 11(2): 161-178.

Flöthe, L. (2019b) 'Representation through information? When and why interest groups inform policymakers about public preferences', Journal of European Public Policy 27(4): 528-546.

Greenwood, J., J.R. Grote and K. Ronit (1992) Organized Interests and the European Community, Volume 2. London: Sage Publications Ltd.

Grömping, M. (2019) 'More Bang for the Buck: Media Freedom and Organizational Strategies in the Agenda-Setting of Human Rights Groups', Political Communication 36(3): 452-475.

Hall, R.L. and A.V. Deardorff (2006) 'Lobbying as legislative subsidy', American Political Science Review 100(1): 69-84.

Hanegraaff, M. (2015) 'Interest groups at transnational negotiation conferences: goals, strategies, interactions, and influence', Global Governance: A Review of Multilateralism and International Organizations 21(4): 599-620.

Hanegraaff, M. (2019) 'Whose side are you on? Explaining the extent to which national interest groups support states in global politics', JCMS: Journal of Common Market Studies 57(3): 563-579.

Hanegraaff, M., J. Vergauwen and J. Beyers (2020) 'Should I stay or should I go? Explaining variation in nonstate actor advocacy over time in global governance', Governance 33(2): 287-304.

Hanegraaff, M. and A. Poletti (2020)' Its economic size, stupid! How global advocacy mirrors state power', Regulation \& Governance, doi: 10.1111/rego.12304

Heaney, M.T., and P. Leifeld. 2018. 'Contributions by Interest Groups to Lobbying Coalitions', Journal of Politics 80(2): 494-509.

Holyoke, T.T. (2009) 'Interest group competition and coalition formation', American Journal of Political Science 53(2): 360-375.

Inglehart, R. and C. Welzel (2009) 'How development leads to democracy: What we know about modernization', Foreign Affairs 88(2): 33-48.

Inglehart, R. and C. Welzel (2010) 'Changing mass priorities: The link between modernization and democracy', Perspectives on Politics 8(2): 551-567.

Klüver, H. (2012) 'Informational lobbying in the European Union: the effect of organizational characteristics', West European Politics 35(3): 491-510. 
Klïver, H. (2013) Lobbying in the European Union: Interest Groups, Lobbying Coalitions, and Policy Change. Oxford: Oxford University Press.

Klüver, H., C. Braun and J. Beyers (2015) 'Legislative lobbying in context: Towards a conceptual framework of interest group lobbying in the European Union', Journal of European Public Policy 22(4): 447-461.

Kollman, K. (1998) Outside Lobbying: Public Opinion and Interest Group Strategies. New York: Princeton University Press.

Leech, B.L., F.R. Baumgartner, T.M. La Pira and N.A. Semanko (2005) 'Drawing lobbyists to Washington: Government activity and the demand for advocacy', Political Research Quarterly 58(1): 19-30.

Lucas, K., M. Hanegraaff and I. De Bruycker (2019) 'Lobbying the lobbyists: when and why do policymakers seek to influence advocacy groups in global governance?' Interest Groups \& Advocacy 8(2): 208-232.

Mahoney, C. (2008) Brussels Versus the Beltway: Advocacy in the United States and the European Union. Washington: Georgetown University Press.

Milner, H.V. and B.P. Rosendorff (1996) 'Trade negotiations, information and domestic politics: The role of domestic groups', Economics \& Politics 8(2): 145-189.

Mulgan, R. (2000) 'Accountability: An ever-expanding concept?' Public Administration 78(3): 555-573.

Narlikar, A. (Ed) (2010) Deadlocks in Multilateral Negotiations: Causes and Solutions. Cambridge: Cambridge University Press.

Schnakenberg, K.E. (2017) 'Informational lobbying and legislative voting', American Journal of Political Science 61(1): 129-145.

Smith, M.A. (2000) American Business and Political Power: Public Opinion, Elections, and Democracy. Chicago: University of Chicago Press.

Stroup, S.S. and A. Murdie (2012) 'Theres no place like home: Explaining international NGO advocacy', The Review of International Organizations 7(4): 425-448.

Suri, K.C. (2004) 'Democracy, economic reforms and election results in India', Economic and Political Weekly 39(51): 54045411.

Tallberg, J., L.M. Dellmuth, H. Agné and A. Duit (2018) 'NGO Influence in International Organizations: Information, access and exchange', British Journal of Political Science 48(1): 213-238.

Willems, E. and I. De Bruycker (2019) 'Balancing constituency and congruence: How constituency involvement affects positional congruence between organized interests and the general public', Governance. doi: 10.1111/gove.12478

Wu, S.Y., J.H. Tang and E.S. Lin (2010) 'The impact of government expenditure on economic growth: How sensitive to the level of development?' Journal of Policy Modeling 32(6): 804-817.

Cite this article: Hanegraaff $\mathrm{M}$ and De Bruycker I (2020). Informational demand across the globe: toward a comparative understanding of information exchange. European Political Science Review 12, 525-543. https://doi.org/10.1017/ S1755773920000284 